\author{
УДК $332.72,330.8,330.101$ \\ JEL Q120, Q150 \\ DOI https://doi.org/10.17721/tppe.2020.41.5
}

\author{
Pimenova O., Associate Professor \\ Taras Shevchenko National University of Kyiv \\ ORCID ID: 0000-0002-5531-6155 \\ Pimenov S., Graduate student \\ Taras Shevchenko National University of Kyiv \\ ORCID ID: 0000-0003-0764-9630
}

\title{
IMPROVING THE EFFICIENCY OF BUSINESS MODEL OF AN ENTERPRISE THROUGH PREPARATION OF INTEGRATED REPORTING
}

The necessity of formation of integrated reporting by Ukrainian enterprises is investigated. The importance of business presentation of information on the company's value creation, its effectiveness, opportunities, risks it faces, and development prospects for investors and other stakeholders in the form of integrated reporting is determined. It is investigated that integrated reporting should provide stakeholders with information on the long-term development of the enterprise in contrast to financial reporting, which cannot provide such full information. That is the main purpose of integrated reporting is to explain to financial capital providers and other stakeholders how an enterprise creates and plans to create the value in the future over a long period of time.

The purpose of the study is to substantiate the need of taking into account the needs of stakeholders in the work of enterprise and the disclosure of non-financial information in the form of integrated reporting, which will increase the efficiency of the business model. The methodological basis of the study is a set of general and special principles, provisions and methods of scientific research, the use of which is determined by the purpose and objectives, in particular, methods of generalization, comparison, analysis and synthesis, methods of system and structural analysis, diagnostic evaluation. In particular, in the process of research the methods of generalization, analysis and synthesis were used in defining the concept of integrated reporting and its individual elements; methods of system and structural analysis in the study of the basic principles of integrated reporting; method of comparison in the study of scientific approaches to the formation of integrated reporting.

It is substantiated that by providing information on value creation, in particular on the company's competitive advantages, strategic assets, environmental, social and management indicators (ESG), the company will gain an advantage over competitors, effectively implementing its business model in the market and be able to achieve sustainable development in the long run.

Keywords: integrated reporting, stakeholders, business model, enterprise efficiency, competitive advantage, sustainable development.

Problem statement. In order to effectively conduct business activities, increasing the social responsibility of business to society, attract green investment, highly qualified personnel to the company, strengthen their competitiveness in modern business conditions, it is not enough to report only on the financial results of the company, as such a report does not give a complete picture to stakeholders on the business model of the enterprise, its development strategy, risks and value creation issues over a long period of 
time. Therefore, in modern business conditions, in order to increase the efficiency of the business model of the enterprise, the tendency of Ukrainian enterprises to form integrated reporting is intensifying, where along with economic indicators of the enterprise also reveals social, environmental and managerial aspects.

Review of recent publications. Theoretical and practical aspects of compiling and preparation of integrated reporting are reflected in the works of such economists as $\mathrm{J}$. Elkington, D. Bayura, O. Grishnova, G. Partin, A. Zagodordniy, K. Bezverkhy and others. Without reducing the importance of scientific developments of Ukrainaian and foreign economists, the issue of compiling integrated reporting has not yet found sufficient elaboration in their development.

Statement of research gap. Despite the growing interest and some research on the formation of integrated reporting in the scientific and business environment, some of its aspects, namely the disclosure of non-financial information about the company remain controversial and require further research. In particular, a new aspect of the study of this topic raises the question of how the provision of information on the social, environmental and managerial sphere of the enterprise to stakeholders will affect the efficiency of the business model of the enterprise.

Stakeholders include individuals and legal entities that have a legitimate interest in the activities of the organization, i.e. to some extent depend on it or can influence its activities (Voronchak, 2009). Each of the stakeholders has an impact on the work of the enterprise of different strength and orientation, which is why providing information on value creation in the long run, the company will gain an advantage over competitors, increasing the efficiency of its business model.

The purpose of the paper. Given the above, the purpose of the study is to substantiate the need to take into account the needs of stakeholders in the work of the enterprise and the disclosure of non-financial information in the form of integrated reporting, which will increase the efficiency of the business model.

Research methodology. The methodological basis of the study is a set of general and special principles, provisions and methods of scientific research, the use of which is determined by the purpose and objectives, in particular, methods of generalization, comparison, analysis and synthesis, methods of system and structural analysis, diagnostic evaluation. In particular, in the process of research the methods of generalization, analysis and synthesis were used in defining the concept of integrated reporting and its individual elements; methods of system and structural analysis in the study of the basic principles of integrated reporting; method of comparison in the study of scientific approaches to the formation of integrated reporting.

The results of the study. Taking into account the interests of stakeholders, disclosure of non-financial information about the work of enterprises, management of non-financial risks, economical treatment of natural and productive resources, improves the quality of management and efficiency of the business model of the enterprise. The concept of longterm sustainable development of the enterprise (sustainability growth) corresponds to the principles that economic growth is an integral part of environmental and social 
consequences. Any economic activity that destroys nature and oppresses the environment, violates human rights is criminal and cannot create long-term value.

The concept of long-term sustainable development of the enterprise is reflected both in the formation of integrated reporting, i.e. reporting in four dimensions (economic, environmental, social and managerial) in accordance with the concept of "triple result (criterion)" and in management decisions based on stakeholders. According to our research, in Ukraine, in contrast to developed countries, only some companies try to conduct socially responsible business. In contrast, a survey of CEOs of UN Global Compact companies found that $93 \%$ of executives worldwide believe that sustainable development is a key factor in future business success (Survey, 2010).

The main principle of realization of the concept of triple result is that the main task of enterprise management is to create growth not only of financial indicators for owners of capital (investors), but also non-financial ones - for stakeholders. The essence of the concept is that when making decisions at the enterprise, managers take into account not only financial results, but also social and environmental consequences, as well as ethical issues. Thus, the concept of a triune result includes the following elements:

- Economic prosperity;

- Social justice and improving the quality of life;

- Preservation and restoration of natural resources.

Based on the concept of the triple result (criterion), J. Elkington (Elkington, 1999) in 1997 developed the Triple win strategy for sustainable business development "3P": People, Planet, Profit ), where:

- People. It is a social component of sustainable development, which is focused on people and aimed at maintaining the stability of social and cultural systems, including the reduction of destructive conflicts in society.

- Planet. From an ecological point of view, this is the integrity of biological and physical natural systems that need to ensure sustainable development. A special place is occupied by the vital activity of ecosystems, on which the global stability of the entire biosphere depends. Therefore, the model focuses on maintaining the ability to recover and dynamically adapt such systems to change. The model also proposes to reduce the impact of factors such as degradation of natural resources, environmental pollution and biodiversity loss.

- Profit. This implies an economic approach to the concept of sustainable development in terms of the criterion of maximizing total income while maintaining the total capital that generates this income. This approach involves the optimal use of limited resources and the use of energy and material-saving technologies, maximum recycling and waste minimization.

The above components of "3P" are a prerequisite for sustainable development of enterprises, and there is a constant interaction between them: the weakening or destruction of one of them leads to the loss of a stable state of the whole enterprise. Based on this, companies need to pay equal attention to improving the efficiency of their activities in the direction of profitability, care for the environment and staff, partners, customers. 
This concept acquires special significance in the conditions of development of modern Ukrainian society and business environment. Its application can lead to greater satisfaction of employees and society with the work of enterprises, and, accordingly - to improve the implementation of their business models with more skilled and motivated employees, support of public authorities and local government, positive attitude of the local community to the enterprise. The 3P concept stipulates that enterprises should focus not exclusively on financial performance and results, but on all aspects of their activities, including stakeholders.

The practical application of the developed and calculated indices of corporate stability and transparency of enterprises is that the high value of indices for a particular enterprise or industry will serve as a catalyst for raising capital, including so-called "green" investments, which are cheaper than traditional. At the same time, these indices show the quality of corporate governance in enterprises, their vulnerability to unforeseen situations and external influences, the ability of enterprises to manage and prevent financial and nonfinancial risks.

Conducting socially responsible business in Ukraine means caring about the growth of the image of the enterprise and the country as a whole, being transparent to society and other stakeholders and being open to innovation and investment.

It should be noted that in today's business environment, socially responsible business attracts not only investors but also consumers (Mind, 2015). Some large multinational companies already require all their partners and suppliers to adhere to ethical standards and the concept of sustainable development. This gives an advantage to those companies that include issues of sustainable development and corporate social responsibility in their business model.

On the other hand, failure to take into account the interests of stakeholders in the civil societies to which Ukraine is heading can lead to serious consequences for businesses, even in some cases to the cessation of activities in certain areas of business. NGOs, the number of which has grown in Ukraine over the last five years, can have a significant impact on the activities of enterprises in certain regions. Various actions and protests often have unpredictable negative consequences for the work of enterprises.

In our opinion, the tasks of business leaders must include the task of timely detection of changes in the mood of employees, local communities, NGOs and the appropriate and immediate response to such changes. This applies to both strategic and operational decisions. At the same time, the finance department (or other unit) should be assigned a new function, which is to quantify the impact of attitudes and actions of stakeholders, in order to timely inform owners and senior managers about the sensitivity of financial performance to changes in the socio-political environment around the enterprise.

At the same time, it is important to see in the changes in the mood of stakeholders not only the threats, but also the opportunities that the company can find and implement in the relevant situation. In the international practice of doing business for more than 10 years, companies in developed countries form integrated reporting to improve the efficiency of their own business models. 
Integrated reporting is reporting that is disclosed by enterprises in four main dimensions: economic, social, environmental and governance. That is, this reporting includes not only financial but also non-financial indicators, in particular: model and strategy of enterprise development, environmental and social component of enterprise activity, model and methods of enterprise management, company development plans, enterprise results, etc. Integrated reporting should provide stakeholders with information on the long-term development of the enterprise in contrast to financial reporting which cannot provide full information. That is the main purpose of integrated reporting is to explain to financial capital providers and other stakeholders how an enterprise creates and plans to create value in the future over a long period of time (International Standard (IO), 2013)

The integrated reporting should be based on the following main components: business model of the enterprise, external environment, opportunities and risks, development strategy of the enterprise, results of activities, management, plans for the development of the company. The purpose of integrated reporting is:

- provide complete information on the long-term development of the enterprise to interested parties;

- reflect the relationship between environmental, social, managerial and economic indicators of the enterprise in the context of sustainable development;

- provide an assessment of the enterprise in the long run;

- provide complete information on the activities of the enterprise.

The preparation of the integrated report, determining its content and method of presenting information are the following basic principles:

- Strategic focus and future orientation. The integrated report should include an analysis of the enterprise's strategy and explain how the strategy relates to the enterprise 's ability to create value in the short, medium and long term, and how the organization uses and manages capital, both equity and debt.

- Ability to connect information. An integrated report should provide a holistic picture of the combinations, relationships, and interdependencies between factors that affect an enterprise 's ability to create value over a long period of time.

- Interaction with stakeholders. The integrated report should contain an analysis and quality of the company's interaction with its main stakeholders. The report should reflect how and to what extent the company understands and takes into account their legitimate and legitimate needs, interests and requests.

- Significance. The integrated report should disclose information on issues among the activities of the enterprise, reflect indicators and information that are important for understanding the work of the enterprise and creating results and values.

- Conciseness. The integrated report should be short enough to disclose information on the one hand and to focus on the main issue in full and volume on the other.

- Reliability and completeness. The integrated report should include all relevant facts, both positive and negative, in a balanced form and without errors.

- Consistency and comparability of information. The data contained in the integrated report should be presented over a long period of time and in such a way that it is possible to compare the company with itself in retrospect and with other companies at the same 
time. This is especially important to test a company's ability to create value over time (International Standard (IO), 2013).

According to Ukrainian scientists Partin G. and Zagorodny A., the integrated report should provide information in two areas (Partin, 2017):

- Information about the results and strategy of the enterprise, its plans and place among competitors;

- Results of interaction with their stakeholders on cooperation programs that have already taken place in previous periods. These results should include indicators against which the company's impact on the activities of its stakeholders can be assessed.

Researchers have also developed a list of such indicators from both groups, which we consider appropriate for companies to use in preparing their integrated reporting, as the indicators cover the interaction with the main groups of stakeholders; most of them do not require additional investment to ensure data collection and analysis; aimed at the future and take into account data from previous periods, which allows you to assess the dynamics of enterprises.

In international practice, integrated reports began to take shape in the mid-2000s. the best nomination "Best Integrated Reporting" appeared at the Corporate Register International Annual Reporting Competition. Later, the Prince of Wales' "Accounting for Sustainability" initiative proposed the Connected Reporting Framework. Subsequently, in 2009 the organization issued another document Connected Reporting, and in 2010 these developments were transferred to the International Council for Integrated Reporting (IIRC) initiated by $A 4 S$ and $G R I$.

Thus, in 2010 the International Integrated Reporting Council (IIRC) was established. Its creation was initiated by the International Federation of Accountants (IFAC), the Global Reporting Initiative (GRI), participants in the Sustainability Report (A4S) project, the International Organization for Standardization (ISO) and others. The main task of the Council was to develop the Concept of Integrated Reporting and prepare a draft International Standard on Integrated Reporting. In 2013, an integrated reporting structure was formed after numerous consultations and tests by companies and investors in various regions of the world, including 140 companies and investors who participated in the IIRC pilot program. This approach assumes that this structure was developed by the business in response to a new, broader value model that:

- provides benefits for stakeholders, in particular investors, as the International Reporting should provide investors with complete information on the development of the enterprise;

- strengthens the leading role of the financial director at the enterprise. Therefore, CFOs are best placed to stimulate integrated reporting as a means of providing information on how their businesses create value over time;

- combines integrated thinking and reporting. Reporting and thinking should complement each other, but at the same time are necessary in enterprises to strengthen communication and expand communication on value creation;

- emphasizes the importance of human capital in the enterprise. 


\section{Conclusions.}

In order to form an effective business model and create additional values in the long run, we believe that in Ukrainian enterprises CEOs, CVOs and CFOs need to provide an environment so that all the necessary information about the company's value creation, its effectiveness, opportunities, risks they face, and development prospects were available to investors and other stakeholders in the form of integrated reporting. By providing information on value creation, in particular on the company's competitive advantages, strategic assets, environmental, social and management indicators (ESG), the company will gain an advantage over competitors, effectively implementing its business model in the market and be able to achieve sustainable development in the long run.

Prospects for further research. In our opinion, the prospects for further research should include a deeper analysis of the needs of stakeholders in the development and implementation of business models of the enterprise on the example of some large enterprises in Ukraine. Also an important question in the formation of an integrated report is what non-financial indicators and areas of significant issues the company needs to disclose to its stakeholders, and how such disclosure affects the effectiveness of business models of enterprises.

\section{Literature}

1. Survey of directors of companies - members of the UN Global Compact (2010). URL: https://www.environmentalleader.com/2010/06/ceos-see-sustainability-as-crucial-to-success/ (дата запиту: 01.04.2020).

2. Elkington, J. (1999). Cannibals with forks: the triple bottom line of 21 st century business. Oxford: Capstone. ISBN 9780865713925 . OCLC 963459936

3. Mind the gaps. The 2015 Deloitte Millennial survey. (2015). URL: https://www2.deloitte.com/content/dam/Deloitte/global/Documents/About-Deloitte/gx-wef-2015millennial-survey-executivesummary.pdf

4. International Council on Integrated Reporting. URL: http://integratedreporting.org/

5. International Integrated Reporting Council «IIRC» (2013) URL: https://integratedreporting.org/wpcontent/uploads/2015/03/13-12-08-THE-INTERNATIONAL-IR-FRAMEWORK.docx_en-US_ru-RU.pdf

6. Partin G., Zagorodniy A. (2017). Taking into account the interests of stakeholders in the process of forming integrated reporting of the enterprise. Bulletin of the National University "Lviv Polytechnic". №862. C.204-210

7. Global Reporting Initiative (GRI) presents Exposure Draft of the Sustainability Reporting Guidelines. (1999). URL: https://www.sustainability-reports.com/global-reporting-initiative-gri-presentsexposure-draft-of-the-sustainability-reporting-guidelines/

8. ISO 9001 FAMILY QUALITY MANAGEMENT. URL: https://www.iso.org/iso-9001-qualitymanagement.html

9. ISO 26000:2010 GUIDE ON SOCIAL RESPONSIBILITY. URL: http://meraua.com/files/ISO_26000_-Rus--draft.pdf

10.Konstantin Bezverkhy (2014). Integrated enterprise reporting: Improving the organization and methods of its compilation. Accounting and auditing №5, 2014. C. 23-28

11.Voronchak, I. (2009). Corporate social responsibility as a socio-economic phenomenon. Responsible economy, №1, 90-103. 


\section{References}

1. Opy tuvannya dy' rektoriv kompanij - uchasny`kiv Global'nogo dogovoru OON (2010). URL: https://www.environmentalleader.com/2010/06/ceos-see-sustainability-as-crucial-to-success/ (data zapy'tu: 01.04.2020).

2. Elkington, J. (1999). Cannibals with forks: the triple bottom line of 21st century business. Oxford: Capstone. ISBN 9780865713925 . OCLC 963459936

3. Mind the gaps. The 2015 Deloitte Millennial survey. (2015). URL: https://www2.deloitte.com/content/dam/Deloitte/global/Documents/About-Deloitte/gx-wef-2015millennial-survey-executivesummary.pdf

4. Mizhnarodna Rada z integrovanoyi zvitnosti. URL: http://integratedreporting.org/ 5. International Integrated Reporting Council «IIRC» (2013) URL:

https://integratedreporting.org/wp-content/uploads/2015/03/13-12-08-THE-INTERNATIONAL-IRFRAMEWORK.docx_en-US_ru-RU.pdf

6. Party'n G., Zagorodnij A. (2017). Uraxuvannya interesiv stejkxolderiv u procesi formuvannya integrovanoyi zvitnosti pidpry 'yemstva. Visny`k Nacional'nogo universy `tetu "L'vivs'ka politexnika". \#862. S.204-210

7. Global Reporting Initiative (GRI) presents Exposure Draft of the Sustainability Reporting Guidelines. (1999). URL: https://www.sustainability-reports.com/global-reporting-initiative-gri-presentsexposure-draft-of-the-sustainability-reporting-guidelines/

8. ISO 9001 FAMILY QUALITY MANAGEMENT. URL: https://www.iso.org/iso-9001-qualitymanagement.html

9. ISO 26000:2010 GUIDE ON SOCIAL RESPONSIBILITY. URL:

http://meraua.com/files/ISO_26000_-Rus--draft.pdf

10. Kostyanty`n Bezverxy j (2014). Integrovana zvitnist` pidpry yemstva: Udoskonalennya organizaciyi i metody 'ky` yiyi skladannya. Buxgalters’ky”j oblik i audy't \#5, 2014. S. 23-28

11. Voronchak, I. (2009). Social'na vidpovidal'nist' biznesu yak social'no-ekonomichny’j fenomen. Vidpovidal'na ekonomika, \#1, 90-103.

Піменова О.В. к.е.Н., доцент,

КНУ імені Тараса Шевченка

Піменов С.А., здобувач

КНУ імені Тараса Шевченка

\section{ПІДВИЩЕННЯ ЕФЕКТИВНОСТІ БІЗНЕС-МОДЕЛІ ПІДПРИЄМСТВА ШЛЯХОМ ПІДГОТОВКИ IHTEГРОВАНОÏ 3ВITHOCTI}

Досліджена необхідність формування інтегрованої звітності українськими підприємствами. Визначено важливість подання бізнесом інфрормації щодо створення підприємством цінностей, його результативності, можливостей, ризиків з якими воно стикається, та перспективи розвитку для інвесторів та інших заінтересованих осіб в формі інтегрованої звітності. Обгрунтовано, що надаючи інформацію про створення цінностей, зокрема про конкурентні переваги підприємства, стратегічні активи, про екологічні, соціальні та управлінські показники (ESG) підприємство отримає перевагу перед конкурентами, ефрективно впроваджуючи свою бізнес-модель на ринку та зможе досягти сталого розвитку в довгостроковій перспективі.

Ключові слова: інтегрована звітність, заінтересовані особи, стейкхолдери, бізнес-модель, ефрективність підприємства, конкурентна перевага, сталий розвиток. 
Пименова Е.В. к.е.н., доцент, КНУ имени Тараса Шевченко

Пименов Сергей, соискатель

КНУ имени Тараса Шевченко

\section{ПОВЫШЕНИЕ ЭФФЕКТИВНОСТИ БИЗНЕС-МОДЕЛИ ПРЕДПРИЯТИЯ ПУТЕМ ПОДГОТОВКИ ИНТЕГРИРОВАННОЙ ОТЧЕТНОСТИ}

Исследована необходимость формирования интегрированной отчетности украинских предприятий. Определена важность представления бизнесом информации о создании предприятием ценности, его результативности, возможностей, рисков с которыми оно сталкивается, и перспективы развития для инвесторов и других заинтересованных лиц в форме интегрированной отчетности. Обосновано, что предоставляя информацию о создании ценности, в частности о конкурентных преимуществах предприятия, стратегических активах, об экологических, социальных и управленческих показателях (ESG) предприятие получит преимущество перед конкурентами, эфффективно внедряя свою бизнесмодель на рынке и сможет достичь устойчивого развития в долгосрочной перспективе .

Ключевые слова: интегрированная отчетность, заинтересованные лица, стейкхолдеры, бизнес-модель, эфффективность предприятия, конкурентное преимущество, устойчивое развитие. 